\title{
WDFY2 Gene
}

National Cancer Institute

\section{Source}

National Cancer Institute. WDFY2 Gene. NCI Thesaurus. Code C122829.

This gene may play a role in ligand binding. 